\title{
PERILAKU KOROSI MATERIAL GELAS METALIK BERBASIS ZIRKONIUM UNTUK MATERIAL IMPLAN
}

\author{
Djony Izak Rudyardjo ${ }^{1)}$ \\ ${ }^{1)}$ Departemen Fisika FST Universitas Airlangga \\ Kampus C Jl. Mulyorejo, Surabaya
}

\begin{abstract}
ABSTRAK
Penelitian ini bertujuan untuk mempelajari perilaku korosi, pengaruh variasi komposisi paduan dan variasi konsentrasi larutan $\mathrm{NaCl}$ terhadap nilai laju korosi material gelas metalik yang berbasis zirkonium, dan untuk mengetahui potensi material gelas metalik berbasis zirkonium untuk material implan. Hasil uji XRD menunjukkan pola difraksi hanya merupakan cacah latar. Selanjutnya, laju korosi $0,36 \% \mathrm{NaCl}$ pada variasi campuran elemen $\mathrm{Zr}_{67} \mathrm{Cu}_{33}, \mathrm{Zr}_{69.5} \mathrm{Cu}_{12} \mathrm{Ni}_{11} \mathrm{Al}_{7.5}$, $\mathrm{Zr}_{70} \mathrm{Ni}_{15} \mathrm{Al}_{15}$ dan $\mathrm{Zr}_{67,6} \mathrm{Cu}_{11,8} \mathrm{Ni}_{10,8} \mathrm{Al}_{7,8} \mathrm{Si}_{2}$ berturut-turut adalah 17,7324 mpy; 13,5916 mpy; 7,1273 mpy da 5.8582 mpy. Variasi campuran elemen mempengaruhi laju korosi dan $\mathrm{Zr}_{67,6} \mathrm{Cu}_{11,8} \mathrm{Ni}_{10,8} \mathrm{Al}_{7,8} \mathrm{Si}_{2}$ mempunyai daya tahan korosi yang baik, karena adanya elemen $\mathrm{Ni}$ dan Si yang membuat reaksi korosi menjadi lambat. Hasil uji korosi pada sampel $\mathrm{Zr}_{69.5} \mathrm{Cu}_{12} \mathrm{Ni}_{11} \mathrm{Al}_{7.5}$ dengan variasi konsentrasi larutan $\mathrm{NaCl} 0,355 \% ; 0,362 \% ; 0,369 \%$ dan $0,376 \%$ berturut-turut adalah 12,0732 mpy; 13,5916 mpy; 19,6227 mpy dan 28.1623 mpy. Hasilnya menunjukkan laju korosi cenderung meningkat dengan peningkatan konsentrasi larutan $\mathrm{NaCl}$. Dari penelitian ini dapat disimpulkan bahwa zirkonium berbasis gelas metalik mempunyai potensi untuk material implan. Hal ini sesuai dengan salah satu syarat untuk material implan, yaitu harus mempunyai daya tahan korosi yang tinggi, sehingga kinerjanya sebagai material implan tidak membahayakan tubuh.
\end{abstract}

Kata kunci: gelas metalik, korosi, material implan

\section{THE BEHA VIOR OF ZIRCONIUM-BASED METALLIC GLASSES FOR IMPLANT MATERIALS}

\begin{abstract}
The aim of this research was to study the corrosion behavior, the effects of composition and concentration variation of $\mathrm{NaCl}$ solution on corrosion rate of zirconium-based metallic glasses, and to ecaluate the potential of this glasses for implant material. The result of XRD test showed that the diffraction pattern was only the back ground. Furthermore, corrosion rates of alloy elements $\mathrm{Zr}_{67} \mathrm{Cu}_{33}, \mathrm{Zr}_{69.5} \mathrm{Cu}_{12} \mathrm{Ni}_{11} \mathrm{Al}_{7.5}, \mathrm{Zr}_{70} \mathrm{Ni}_{15} \mathrm{Al}_{15}$ and $\mathrm{Zr}_{67,6} \mathrm{Cu}_{11,8} \mathrm{Ni}_{10,8} \mathrm{Al}_{7,8} \mathrm{Si}_{2}$ in $0,36 \% \mathrm{NaCl}$ were 17,7324 mpy; 13,5916 mpy; 7,1273 mpy and $5.8582 \mathrm{mpy}$, respectively. Variation of alloy element affected the corrosion rate. $\mathrm{Zr}_{67,6} \mathrm{Cu}_{11,8} \mathrm{Ni}_{10,8} \mathrm{Al}_{7,8} \mathrm{Si}_{2}$ had the best corrosion resistant because of the present of $\mathrm{Ni}$ and $\mathrm{Si}$, so that the corrosion reaction occured slower. The corrosion rate of corrosion test on $\mathrm{Zr}_{69.5} \mathrm{Cu}_{12} \mathrm{Ni}_{11} \mathrm{Al}_{7.5}$ in $0,355,0,362,0,369$ and $0,376 \% \mathrm{NaCl}$ were 12,0732 mpy, 13,5916 mpy, 19,6227 mpy and 28'1623 mpy respectively. The results indicated that increasing the concentration of $\mathrm{NaCl}$ solution tended to increase the corrosion rate. It could be concluded that zirconium-based metallic glasses has potential for implant material. As this material had the higest, it was suitable for implant material and it did not andanger our body due to corrosion process.
\end{abstract}

Keywords: metallic glasses, corrosion, implant materials

\section{PENDAHULUAN}

Aplikasi material di dunia medis mengenal adanya implantasi dalam ilmu bedah tulang atau biasa disebut orthopaedic dimana banyak digunakan baja tahan karat atau material logam lainnya untuk membantu dan menggantikan fungsi bagian tubuh 
tertentu. Alat bantu yang dipergunakan untuk penyambungan tulang patah antara lain : sekrup tulang (bone screw), plat tulang (bone plate), nail plate, total hip prosthesis sesuai dengan fungsi dan kebutuhannya masingmasing.

Bagi tubuh manusia, alat-alat bantu penyambung tulang tersebut merupakan benda asing yang harus menyesuaikan diri dengan lingkungannya berupa cairan darah. Telah diketahui bahwa darah mengandung 355 - 376 mg klorida per $100 \mathrm{ml}$ cairan darah (Grollman, Sigmund, 1974).

Penelitian untuk mendapatkan material baru dengan kinerja tinggi banyak dilakukan orang, khususnya di negara-negara industri seperti Amerika, Eropa dan Jepang. Salah satu bahan baru yang saat ini sedang dikembangkan adalah bahan logam dengan struktur amorf yang mempunyai sifat keuletan tinggi, dan sering disebut gelas metalik (metallic glasses). Pada struktur gelas atomatom tersusun secara periodik, tetapi tidak berjangkauan panjang. Struktur gelas metalik pertama kali ditemukan oleh P. Duwez untuk paduan $\mathrm{Au}$ - Si pada tahun 1960 (Klement, Willens,Duwez 1960, Nature, 187, 869).

Ketahanan korosi tinggi merupakan salah satu syarat yang harus dimiliki oleh suatu biomaterial. Korosi merupakan suatu bentuk degradasi kualitas material akibat adanya reaksi kimia dengan lingkungan. Perbaikan kinerja material terkait dengan sifat-sifatnya dapat dilakukan melalui beberapa cara, salah satu diantaranya adalah memvariasi komposisi dengan mengubah konsentrasi atau menambahkan elemen pemadu (Flemings,Cahn ., 2000, Acta Mater .48, 371-383). Penelitian ini bertujuan untuk menentukan nilai laju korosi material gelas metalik berbasis zirkonium dalam lingkungan $\mathrm{NaCl}$, mempelajari pengaruh variasi komposisi paduan dan variasi konsentrasi $\mathrm{NaCl}$ terhadap nilai laju korosi material gelas metalik berbasis zirkonium, serta mengetahui potensi material gelas metalik berbasis zirkonium untuk material implan.

Besar pengaruh komposisi dan konsentrasi $\mathrm{NaCl}$ pada ketahanan korosi dari material gelas metalik dalam tubuh manusia dapat diketahui dengan melakukan uji ketahanan korosi material amorf tersebut dengan variasi komposisi dan konsentrasi $\mathrm{NaCl}$. Uji korosi dilakukan dalam media larutan garam $\mathrm{NaCl}$, karena komposisinya mendekati komposisi cairan darah manusia.

Pada makalah ini disajikan hasil penelitian pengaruh variasi komposisi dan konsentrasi larutan $\mathrm{NaCl}$ paduan material gelas metalik berbasis zirkonium terhadap nilai laju korosi dalam lingkungan $\mathrm{NaCl}$ serta potensi material gelas metalik berbasis zirkonium untuk material implan. Penelitian ini diharapkan dapat memberikan informasi ilmiah mengenai perilaku korosi, nilai laju korosi dan pengaruh variasi komposisi dan konsentrasi $\mathrm{NaCl}$ terhadap nilai laju korosi material gelas metalik berbasis zirkonium dalam lingkungan $\mathrm{NaCl}$ sehingga dapat ditemukan jenis material baru dengan ketahanan korosi yang jauh lebih baik untuk diaplikasikan sebagai material implan.

\section{METODOLOGI PENELITIAN}

Paduan amorf berbasis $\mathrm{Zr}$ terdiri dari $\mathrm{Zr}_{67} \mathrm{Cu}_{33} ; \quad \mathrm{Zr}_{70} \mathrm{Ni}_{15} \mathrm{Al}_{15} ; \quad \mathrm{Zr}_{69,5}, \mathrm{Cu}_{12} \mathrm{Ni}_{11} \mathrm{Al}_{7,5}$; $\mathrm{Zr}_{67,6} \mathrm{Cu}_{11,8} \mathrm{Ni}_{10,8} \mathrm{Al}_{7,8} \mathrm{Si}_{2}$ at.\% dipersiapkan. Menguji material amorf dengan XRD untuk mengetahui fasa amorf dari pola difraksi yang dihasilkan. Pengukuran dilakukan pada temperatur kamar $22^{\circ} \mathrm{C}$ dengan tegangan 40 $\mathrm{kV}$ dan arus $30 \mathrm{~mA}$ dengan menggunakan target $\mathrm{Cu}$. Pengujian dilakukan dengan range sudut $2 \theta$ dari $5^{\circ}$ sampai $90^{\circ}$ dengan kenaikan sudut sebesar $0,02^{\circ}$. Potongan dari material berstruktur amorf dibentuk sebagai elektroda; berupa silinder pipih dengan diameter $13 \mathrm{~mm}$. Oleh karena sampel berupa pita (ribbon) tipis, maka sampel diletakkan di atas permukaan aluminium foil yang telah dibentuk sebagai wadah sampel dengan diameter $15 \mathrm{~mm}$. Masing-masing sampel permukaannya dibuat halus dan rata. Kemudian seluruh sampel diuji nilai laju korosinya dengan cara menentukan intensitas arus korosinya menggunakan Potensiostat PGS 210T dalam media korosi larutan $\mathrm{NaCl}$ dengan komposisi $355 \mathrm{mg} \mathrm{NaCl}$ per $100 \mathrm{~mL}$ aquades, $362 \mathrm{mg} \mathrm{NaCl}$ per $100 \mathrm{~mL}$ aquades, $369 \mathrm{mg} \mathrm{NaCl}$ per $100 \mathrm{~mL}$ aquades , $376 \mathrm{mg}$ $\mathrm{NaCl}$ per $100 \mathrm{~mL}$ aquades. Pengukuran dilakukan dengan memberikan potensial pada elektrode kerja dari - $2500 \mathrm{mV}$ sampai +1000 $\mathrm{mV}$ dengan laju scan $20 \mathrm{mV}$ per sekon. Setelah dilakukan "starting" program pada potensiostat PGS 201-T terhadap bahan uji 
diperoleh kurva potensial lawan log intensitas arus. Dari kurva tersebut dapat dihitung laju korosi tiap-tiap sampel.

\section{HASIL DAN PEMBAHASAN}

\section{A. Hasil Uji X-Ray Difractometer (XRD) terhadap Struktur Bahan atau Fasa yang Terbentuk}

Hasil pengujian difraksi sinar-X pada sampel nampak bahwa pola difraksi yang dihasilkan sampel $\mathrm{Zr}_{67} \mathrm{Cu}_{33}$ hanya merupakan cacah latar (back ground). Hal ini menunjukkan bahwa struktur bahan atau fasa yang terbentuk dari sampel $\mathrm{Zr}_{67} \mathrm{Cu}_{33}$ adalah amorf.

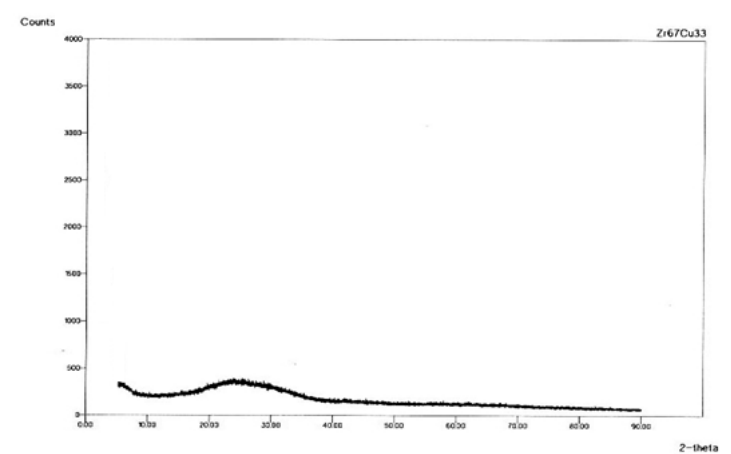

Gambar 1. Pola difraksi sinar-x sampel

$$
\mathrm{Zr}_{67} \mathrm{Cu}_{33}
$$

\section{B. Pengaruh Variasi Elemen Pemaduk terhadap Nilai Laju Korosi Sampel}

Untuk mengetahui nilai laju korosi sampel dilakukan pengujian menggunakan metode polarisasi potensiostatik PGS 201-T. Setelah dilakukan "starting" program pada potensiostat PGS 201-T terhadap bahan uji, diperoleh kurva potensial lawan log intensitas arus. Dari kurva tersebut dapat dihitung laju korosi tiap-tiap sampel. Sebelum menghitung laju korosi tiap-tiap sampel, maka perlu dihitung terlebih dahulu berat equivalen dan densitas masing-masing sampel sehingga akan didapat laju korosi. Kurva potensial lawan $\log$ intensitas arus untuk bahan uji dengan variasi jenis elemen pemadu yaitu $\mathrm{Zr}_{67} \mathrm{Cu}_{33}, \quad \mathrm{Zr}_{70} \mathrm{Ni}_{15} \mathrm{Al}_{15}, \quad \mathrm{Zr}_{69.5} \mathrm{Cu}_{12} \mathrm{Ni}_{11} \mathrm{Al}_{7.5}$ $\mathrm{Zr}_{67,6} \mathrm{Cu}_{11,8} \mathrm{Ni}_{10,8} \mathrm{Al}_{7,8} \mathrm{Si}_{2}$ pada konsentrasi $\mathrm{NaCl} 0,362 \%$ disajikan pada Gambar 2. Dengan melakukan analisis tafel secara semi manual diperoleh nilai arus korosi $\mathrm{I}_{\mathrm{kor}}$.

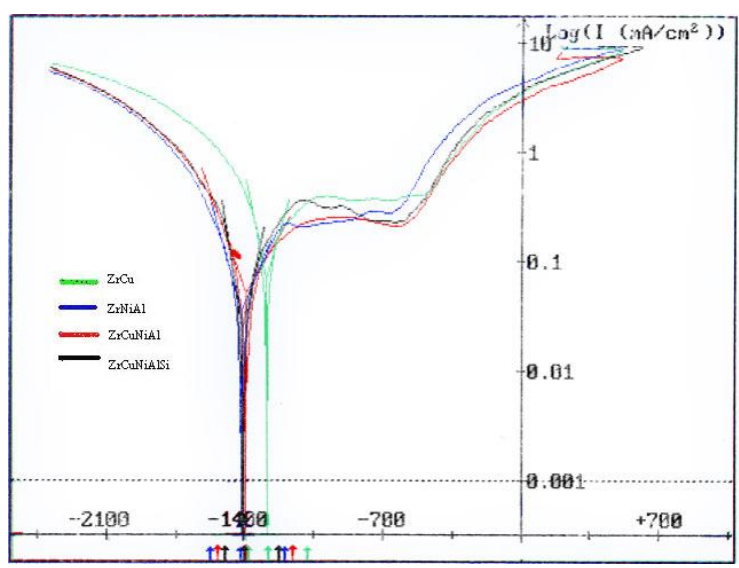

Gambar 2. Kurva tafel berdasarkan variasi elemen pemadu

Hasil perhitungan nilai laju korosi dari masing-masing sampel dalam larutan uji $\mathrm{NaCl}$ 0,362\% disajikan pada Tabel 1.

Tabel 1. Hasil perhitungan nilai laju korosi dari sampel dengan variasi jenis elemen pemadu pada konsentrasi $\mathrm{NaCl} 0,362 \%$

\begin{tabular}{|c|l|c|c|c|}
\hline No & \multicolumn{1}{|c|}{ Jenis Sampel } & $\begin{array}{c}\text { Konsentrasi } \\
\mathbf{N a C l} \\
(\boldsymbol{\%})\end{array}$ & $\begin{array}{c}\mathbf{I}_{\text {kor }} \\
\left(\boldsymbol{\mu A} \mathbf{A} / \mathbf{c m}^{2}\right)\end{array}$ & $\begin{array}{c}\text { Laju Korosi } \\
(\mathbf{m p y})\end{array}$ \\
\hline 1 & $\mathrm{Zr}_{67} \mathrm{Cu}_{33}$ & 0,362 & 66,04 & $29,4358 \times 10^{-24}$ \\
\hline 2 & $\mathrm{Zr}_{69.5} \mathrm{Cu}_{12} \mathrm{Ni}_{11} \mathrm{Al}_{7.5}$ & 0,362 & 49,59 & $22,5620 \times 10^{-24}$ \\
\hline 3 & $\mathrm{Zr}_{70} \mathrm{Ni}_{15} \mathrm{Al}_{15}$ & 0,362 & 34,06 & $11,8313 \times 10^{-24}$ \\
\hline 4 & $\mathrm{Zr}_{67,6} \mathrm{Cu}_{11,8} \mathrm{Ni}_{10,8} \mathrm{Al}_{7,8} \mathrm{Si}_{2}$ & 0,362 & 22,79 & $9,7247 \times 10^{-24}$ \\
\hline
\end{tabular}

Dari hasil di atas nampak bahwa sampel tiga, empat dan lima komponen lebih resistan terhadap korosi dibandingkan dengan sampel dua komponen. Pada sampel dua komponen elemen $\mathrm{Cu}$ memiliki pengaruh besar terhadap material gelas metalik. Elemen $\mathrm{Cu}$ berpengaruhmempercepatkristalisasi (Inoue and Louzguine, 2000). Hal ini 
dikarenakan $\mathrm{Cu}$ memiliki kemampuan untuk berdifusi ke dalam $\mathrm{Zr}$ sehingga pembentukan struktur kristal lebih mudah pada gelas biner untuk fasa $\mathrm{ZrCu}$. Struktur kristal pada material gelas metalik lebih mudah terkorosi dibandingkan material berstruktur amorf dalam lingkungan $\mathrm{NaCl}$ (Schroeder, Gilbert and Ritchie, 1998). Hal ini yang menyebabkan sampel dua komponen paling cepat terkorosi dibanding sampel lainnya. Kehadiran elemen $\mathrm{Ni}$ yang tahan terhadap korosi dalam berbagai lingkungan (Trethtwey,1991) dan elemen Al yang mampu membentuk oksida logam sebagai pelindung permukaan logam menyebabkan sampel empat komponen memiliki ketahanan korosi yang lebih baik daripada sampel dua komponen.

Sampel tiga komponen menunjukkan ketahanan korosi yang lebih baik lagi dibanding dua sampel sebelumnya. Ketidakhadiran elemen $\mathrm{Cu}$ mampu memperbaiki kestabilan fasa amorf pada sampel gelas metalik ini sehingga sampel lebih tahan terhadap serangan korosi. Ketahanan korosi ini menyebabkan proses korosi yang berlangsung lambat dan ditunjukkan oleh kurva tafel untuk tiga, empat dan lima komponen terbentuk lebih rendah daripada dua komponen (lihat Gambar 2). Bentuk kurva tersebut menggambarkan bahwa arus korosi terjadi pada nilai yang lebih kecil, hal ini berarti laju korosi dari sampel juga menghasilkan nilai yang kecil pula. Sedangkan jenis sampel yang paling resistan terhadap korosi adalah sampel lima komponen yaitu $\mathrm{Zr}_{67,6} \mathrm{Cu}_{11,8} \mathrm{Ni}_{10,8} \mathrm{Al}_{7,8} \mathrm{Si}_{2}$. Penambahan elemen $\mathrm{Si}$ dapat menghambat reaksi reduksi dan oksidasi, hal ini disebabkan $\mathrm{Si}$ memiliki harga potensial standart yaitu sebesar -0,13 dimana nilai ini lebih positif dari nilai potensial standart $\mathrm{Al}$ dan Ni yang berturut turut sebesar -1,706 dan $-0,23$ sehingga sampel lima komponen sulit teroksidasi akibatnya juga sulit mengalami korosi. Selain itu elemen Si yang dipadukan pada material gelas metalik mampu memperbaiki sifat dan stabilitas struktur dari Glass Forming Ability, sehingga sampel memiliki sifat amorf yang lebih baik dan lebih tahan terhadap serangan korosi. Pada dasarnya penambahan elemen pemadu pada material gelas metalik berbasis zirkonium dimaksudkan untuk mempermudah pembentukan paduan dan meningkatkan kualitas dari Glass Forming Ability (Wang, dkk, 2007).

Proses korosi yang berlangsung lambat pada sampel lima komponen tergambarkan pada kurva tafel yang terbentuk paling rendah dan curam. Berdasarkan persamaan 2.2 untuk menentukan nilai arus korosi dipengaruhi oleh kemiringan (slope) dari kurva. Kecuraman kurva akan menunjukkan arus korosi terjadi pada nilai yang rendah, dan hal ini mempengaruhi nilai laju korosi yang semakin kecil pula.

Berdasarkan hasil uji korosi pada masing-masing material gelas metalik berbasis zirkonium yang memberikan nilai laju korosi yang sangat kecil, maka material gelas metalik berbasis zirkonium mempunyai potensi untuk digunakan sebagai material implan. Hal ini dapat ditunjukkan dari nilai arus korosi yang diperoleh berdasarkan hasil uji korosi terhadap material tersebut mendekati dengan nilai arus korosi yang dimiliki oleh salah satu material implan tulang yang digunakan paramedis saat ini yaitu material Ti-6Al-4V sebesar 0,16 $\mu \mathrm{A} / \mathrm{cm}^{2}$ (Choubey Animesh, Basu, and Balasubramaniam, 2004). Nilai laju korosi yang kecil ini menunjukkan bahwa material gelas metalik berbasis zirkonium memiliki ketahanan korosi yang tinggi. Hal ini sesuai dengan salah satu syarat mutlak bagi suatu material implan yaitu material tersebut harus memiliki ketahanan korosi yang tinggi sehingga dalam kinerjanya sebagai material orthopaedic tidak menimbulkan efek yang berbahaya bagi tubuh akibat proses korosi. Apabila material tersebut terkorosi dalam tubuh, maka akan memberi dua pengaruh yang sangat merugikan, pengaruh yang pertama adalah implan tersebut melemah sehingga terjadi kegagalan yang prematur. Kedua adalah reaksi jaringan yang mendorong ke arah pelepasan produk-produk karat dari implan sehingga menyebabkan alergi pada jaringan. Dari hasil uji korosi pada masing-masing material gelas metalik berbasis zirkonium tersebut dapat diketahui bahwa paduan yang paling berpotensi untuk digunakan sebagai material implan dalam kajian nilai laju korosinya adalah paduan $\mathrm{Zr}_{67,6} \mathrm{Cu}_{11,8} \mathrm{Ni}_{10,8} \mathrm{Al}_{7,8} \mathrm{Si}_{2}$. Selain laju korosinya yang kecil potensi material gelas metalik berbasis zirkonium sebagai material implan juga ditunjukkan dari sifat mekanisnya yang baik seperti nilai Tensile strength sebesar 
1700 Mpa dan batas elastisitas sebesar 2\% (Horton, and Parsell, 2000). Nilai ini jauh lebih baik bila dibandingkan dengan nilai yang dimiliki oleh material logam lain.

\section{Pengaruh Variasi Konsentrasi Larutan NaCl terhadap Nilai Laju Korosi Sampel}

Selanjutnya kurva potensial lawan log intensitas arus untuk bahan uji $\mathrm{Zr}_{69.5} \mathrm{Cu}_{12} \mathrm{Ni}_{11} \mathrm{Al}_{7.5}$ dengan variasi konsentrasi $\mathrm{NaCl}$ yaitu $0,355 \% ; 0,362 \% ; 0,369 \%$ dan 0,376\% disajikan pada Gambar 3

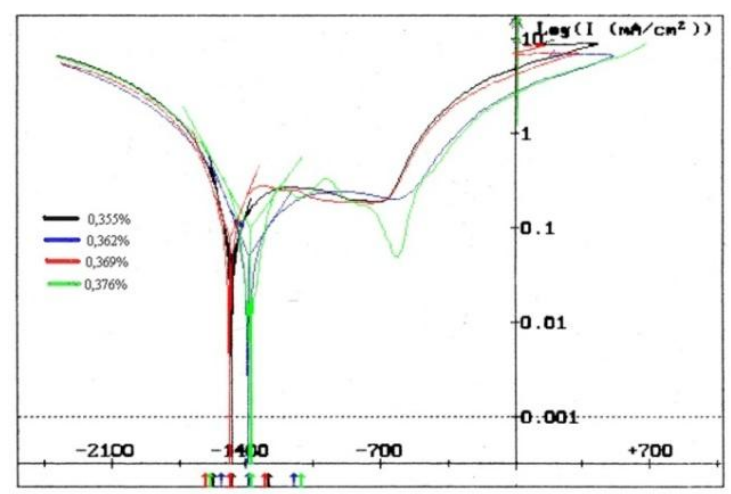

Gambar 3. Kurva tafel berdasarkan variasi konsentrasi $\mathrm{NaCl}$
Dari Gambar 3 terlihat bahwa serangan agresif ion $\mathrm{Cl}^{-}$meningkatkan laju reaksi oksidasi dan reduksi, hal ini nampak pada letak perpotongan garis singgung kurva. Letak perpotongan garis singgung kurva yang semakin tinggi seiring peningkatan konsentrasi larutan $\mathrm{NaCl}$ menunjukkan arus korosi terjadi pada nilai yang tinggi sehingga laju korosi semakin meningkat.

Hasil perhitungan nilai laju korosi sampel $\mathrm{Zr}_{69.5} \mathrm{Cu}_{12} \mathrm{Ni}_{11} \mathrm{Al}_{7.5}$ untuk masingmasing konsentrasi larutan uji $\mathrm{NaCl}$ disajikan pada Tabel 2. Sedangkan grafik hubungan antara variasi konsentrasi larutan uji $\mathrm{NaCl}$ dengan nilai laju korosi sampel $\mathrm{Zr}_{69.5} \mathrm{Cu}_{12} \mathrm{Ni}_{11} \mathrm{Al}_{7.5}$ disajikan pada Gambar 4 .

Tabel 2. Hasil perhitungan nilai laju korosi sampel $\mathrm{Zr}_{69.5} \mathrm{Cu}_{12} \mathrm{Ni}_{11} \mathrm{Al}_{7.5}$ dengan variasi konsentrasi larutan uji $\mathrm{NaCl}$

\begin{tabular}{|c|c|c|c|c|}
\hline No & Jenis Sampel & $\begin{array}{c}\text { Konsentrasi NaCl } \\
(\boldsymbol{\%})\end{array}$ & $\begin{array}{c}\mathbf{I}_{\text {kor }} \\
\left.\left(\boldsymbol{\mu} \mathbf{A} / \mathbf{c m}^{2}\right)\right)\end{array}$ & $\begin{array}{c}\text { Laju Korosi } \\
(\mathbf{m p y})\end{array}$ \\
\hline 1 & $\mathrm{Zr}_{69.5} \mathrm{Cu}_{12} \mathrm{Ni}_{11} \mathrm{Al}_{7.5}$ & 0,355 & 44,05 & $20,0417 \times 10^{-24}$ \\
\hline 2 & $\mathrm{Zr}_{69.5} \mathrm{Cu}_{12} \mathrm{Ni}_{11} \mathrm{Al}_{7.5}$ & 0,362 & 49,59 & $22,5620 \times 10^{-24}$ \\
\hline 3 & $\mathrm{Zr}_{69.5} \mathrm{Cu}_{12} \mathrm{Ni}_{11} \mathrm{Al}_{7.5}$ & 0,369 & 75,08 & $32,5737 \times 10^{-24}$ \\
\hline 4 & $\mathrm{Zr}_{69.5} \mathrm{Cu}_{12} \mathrm{Ni}_{11} \mathrm{Al}_{7.5}$ & 0,376 & 97,06 & $46,7495 \times 10^{-24}$ \\
\hline
\end{tabular}

Dari hasil tersebut (Tabel 2) nampak bahwa semakin tinggi konsentrasi larutan $\mathrm{NaCl}$ maka laju korosi sampel material gelas metalik berbasis zirkonium menjadi semakin meningkat (lihat Gambar 4). Hal ini disebabkan karena dengan adanya konsentrasi yang semakin tinggi dari larutan uji $\mathrm{NaCl}$, maka konsentrasi ion $\mathrm{Cl}^{-}$meningkat. Hal ini dikarenakan ion $\mathrm{Cl}^{-}$sulit untuk berikatan kembali dengan ion $\mathrm{Na}^{+}$di dalam air, sehingga ion-ion $\mathrm{Cl}^{-}$tersebut dengan mudah menyerang (mengkorosi) sampel tersebut.
Dari grafik hubungan antara variasi konsentrasi larutan uji $\mathrm{NaCl}$ dengan nilai laju korosi sampel $\mathrm{Zr}_{69.5} \mathrm{Cu}_{12} \mathrm{Ni}_{11} \mathrm{Al}_{7.5}$ sebagaimana disajikan pada Gambar 4.10 terlihat bahwa pada variasi konsentrasi $\mathrm{NaCl}$ antara $0,355 \%$ dan $0,362 \%$ perubahan nilai laju korosi sampel kurang signifikan. Hal ini disebabkan karena serangan agresif ion $\mathrm{Cl}^{-}$kurang efektif terhadap sampel, sehingga proses korosi terjadi secara lambat. Sedangkan pada konsentrasi $\mathrm{NaCl}$ yang lebih tinggi yaitu $0,369 \%$ terjadi peningkatan nilai laju korosi 
yang cukup signifikan dan menjadi lebih besar pada konsentrasi $0,376 \%$. Hal ini menunjukkan serangan agresif ion $\mathrm{Cl}^{-}$ menjadi lebih efektif terhadap sampel, sehingga proses korosi terjadi lebih cepat.

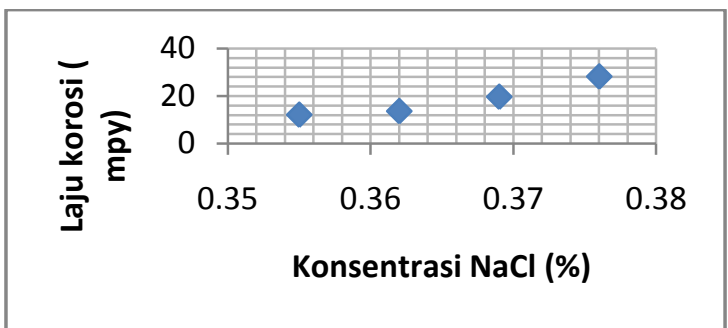

Gambar 4. Grafik hubungan antara variasi konsentrasi larutan uji dengan nilai laju korosi sampel $\mathrm{Zr}_{69.5} \mathrm{Cu}_{12} \mathrm{Ni}_{11} \mathrm{Al}_{7.5}$

\section{KESIMPULAN}

Dari hasil pengujian, pengamatan, serta hasil dan pembahasan yang telah dilakukan dalam penelitian ini, dapat diambil kesimpulan sebagai berikut :

1. Nilai laju korosi dapat ditentukan dari nilai arus korosi yang diperoleh dari kurva potensial terhadap log arus.

2. Kehadiran elemen pemadu $\mathrm{Cu}, \mathrm{Ni}, \mathrm{Al}$ dan $\mathrm{Si}$ mempengaruhi nilai laju korosi pada material gelas metalik berbasis zirkonium. Untuk material $\mathrm{Zr}_{67,6} \mathrm{Cu}_{11,8} \mathrm{Ni}_{10,8} \mathrm{Al}_{7,8} \mathrm{Si}_{2}$ mempunyai resistansi terhadap korosi yang paling baik karena kehadiran elemen $\mathrm{Ni}$ dan Si dalam komposisi paduan mampu mengendalikan laju korosi pada sampel gelas metalik berbasis zirkonium.

3. Besarnya konsentrasi larutan $\mathrm{NaCl}$ berpengaruh terhadap nilai laju korosi. Semakin tinggi larutan $\mathrm{NaCl}$ maka nilai laju korosi material gelas metalik berbasis zirkonium $\mathrm{Zr}_{69.5} \mathrm{Cu}_{12} \mathrm{Ni}_{11} \mathrm{Al}_{7.5}$ menjadi semakin meningkat. Hal ini disebabkan karena konsentrasi ion $\mathrm{Cl}^{-}$meningkat, sehingga serangan ion agresif $\mathrm{Cl}^{-}$terhadap sampel semakin meningkat.

4. Material gelas metalik berbasis zirkonium mempunyai potensi untuk digunakan sebagai material implan berdasarkan ketahanan korosi yang tinggi yaitu mendekati ketahanan korosi material Ti6Al-4V dan sifat mekaniknya yang baik. Hal ini sesuai dengan salah satu syarat mutlak bagi suatu material implan yaitu material tersebut harus memiliki sifat biokompatibel dan biomekanik sehingga dalam kinerjanya sebagai material implan orthopaedic tidak menimbulkan efek yang berbahaya bagi tubuh.

\section{DAFTAR PUSTAKA}

Callister, W. D. 1985. Material Science and Enginnering: An Introduction. John Willey and Sons Inc, New York.

Chen, M.W., dkk. 1999. Aplly Physics Letters. 74 , (6), 812-814.

Choubey, Animesh, R. Basu, R. Balasubramaniam. 2004. Electrochemical Behavior of Intermetallic $\mathrm{Ti}_{3} \mathrm{Al}$-based Alloys in Simulted Human Body Fluid Environment. Intermetallics 679-682, India.

Flemings, M.C., and R.W. Cahn. 2000. Acta Mater .48, 371-383

Grollman and Sigmund. 1974. The Human Body : Its Structure and Physiology, Third edition. Macmillan Publishing Co. Inc., New York, Collier Macmillan Publishers, London.

Hiromoto, S., A.P. Tsai, M. Sumita, T. Hanawa. 2001. Corrosion Behavior of $\mathrm{Zr}_{65} A l_{7,5} \mathrm{Ni}_{17,5}$ Amorphous Alloy for Biomedical Use. National Research Institute for Metals, Tsukuba 305-0047, Japan.

Horton, J. A. and D. E. Parsell. 2000. Biomedical Potential of a ZirconiumBased Bulk Metallic Glass, Metals and Ceramics Division, Oak Ridge National Laboratory, Oak Ridge. TN 378316115.

Inoue, A. and T. Zhang. 1996. Fabrication of Bulk Glassy $\mathrm{Zr}_{55} \mathrm{Al}_{10} \mathrm{Ni}_{5} \mathrm{Cu}_{30}$ of $30 \mathrm{~nm}$ in Diameter by a Suction Casting Method. Mat. Trans JIM. 37, 185-187.

Inoue, A. and D.V. Louzguine. 2000. Crystallization Behaviour of $\mathrm{Ti}_{50} \mathrm{Ni}_{25} \mathrm{Cu}_{25}$ Amorphous Alloy. JMS 35, Halaman 4159-4164. 
Jang, J.S.C., dkk. 2004. Crystallization Behavior of the $\mathrm{Zr}_{61} \mathrm{Al}_{7.5} \mathrm{Cu}_{17.5} \mathrm{Ni}_{10} \mathrm{Si}_{4}$ Amorphous Alloy. Departement of Materials Science and Enginering, ISHOU University, Taiwan.

Klement, W., R.H. Willens, and P. Duwez. 1960. Nature. 187, 869.

Koester and Uwe. 1993. Phase Transformation in Rapidly Solidification Alloy. Key Engineering Material 81-83, Halaman 647-662.

Kuhn, U., J. Eckert, N. Mattren, and L. Schultz. 2000. Apply Physics Letters. 77, (20), 3167-3178.

Ladd, M.F.C and R.A. Palmer. 1977. Structure Determination by X-Ray Crystallography. Plenum Press, New York.

Lawrence H. and Van Vlack. 1995. Element of Material Science and Engineering. Addison- Wesley Publishing Company, USA.

Lee, J.K., G. Choi, D.H.. Kim and W.T. Kim, W.T. 2000. Apply Physics Letters. 77, (7), 978-980.

Pearce, and Evelyn. 1991. Anatomy \& Physiology for Nurses. Evelyn Pearce, alih bahasa Gramedia Pustaka Utama. PT., Anatomi \& Fisiologi untuk Paramedis, Jakarta.

Roziqin, and M. Mukhlas. 2005. Perilaku Korosi Material Amorf gelas Metalik Berbasis Zirkonium dengan Metode Polarisasi Potensiostatik. Skripsi Jurusan Fisika Universitas Airlangga.

Schroers, Jan and L. William L. Johnson. $2000 . \quad$ History Dependent Cristallisation of $\mathrm{Zr}_{41} \mathrm{Ti}_{14} \mathrm{Cu}_{12} \mathrm{Ni}_{10} \mathrm{Be}_{23}$ Melt. Journal of Applied Physics Vol 88 No. 1.

Schroeder, V., C.J. Gilbert and R.O. Ritchie. 1998. Comparison of the Corrosion Behaviour of Bulk Amorphous Metal ZrTiCuNiBe with Its Crystallized Form. Department of Material and Mineral Engineering, University of California.

Silver F. H. 1994. Biomaterials Medical Devices and Tissue Enginering An Intergrated Approach. London.
Shrerr, LL., R.A. Jarman and G.T. Burstein. 1994. Corrosion Metal/ Environment Reaction, Third edition vol 1 . Butterworth, Heinemann Ltd. Linere House, Jourdan Hill. Oxford.

Trethtwey, K.R. 1991. Korosi untuk Mahasiswa Sains dan Rekayasawan. PT. Gramedia Pustaka Utama, Jakarta.

Von Recum, A. F. 1999. Handbook of Biomaterials Evaluation - Scientific, Technical and Clinical Testing of Implant Materials, 2nd edn, Philadelphia: Taylor \& Francis.

Wahyuni, I.T. 2007. Perilaku Korosi Material Berstruktur Kristal dari Bahan Dasar Amorf Berbasis Zirkonium dengan Metode Polarisasi Potensiostatik. Skripsi Jurusan Fisika Universitas Airlangga .

Wang, M.W., dkk. 2007. Effect of Si on the Glass-Forming Ability, Thermal Stability and Magneti properties of $\mathrm{Fe}-$ $\mathrm{Co}-\mathrm{Zr}-\mathrm{Mo}-\mathrm{W}-\mathrm{B}$ alloys. Institute for Metallic Materials, IFW Dresden, P.O. 270016, Dresden D-01171, Germany.

Xing, L.Q., dkk. 1999. Appl. Phys. Lett. 74, (5), 664-666. 